\title{
On the ideological underpinnings of the theory of speech acts
}

Kanavillil Rajagopalan UNICAMP

\section{Resumo}

Este trabalho procura pleitear que a Teoria dos Atos de Fala, tal qual ela foi reformulada pelo filósofo norte-americano J. R. Searle, tem uma dimensão fortemente ideológico-política. Essa constatação em si não deveria despertar nenhum espanto, não fosse o fato de que os filósofos 'analíticos', contrariamente aos assim chamados 'Continentais', costumam insistir em que suas posições fllosóficas estão acima de qualquer ideologia. A argumentação desenvolvida neste trabalho se baseia numa leitura crítica de um tratado político (pouco conhecido entre nós) da autoria de Searle, intitulado de The Campus War, a fim de mostrar que, em última análise, a ideologia que sustenta a obra é a mesma que se depreende das demais obras do filósofo. 
I am convinced that speech act theory is fundamentally and in its most fecund, most rigorous and most interesting aspects (need I recall that it interests me considerably?) a theory of right or law, of convention, of political etbics or of politics as etbics ...

- Jacques Derrida, 'Limited Inc, abc...'.

\section{PRELIMINARY REMARKS}

he theory of speech acts, in the form in which we know it, is due in large measure to the highly significant contribution of John R. Searle of the University of California, Berkeley, who came across the basic ingredients of the theory in the pioneering work of his mentor, the Oxford philosopher, J.L. Austin. Although this fact has not gone unnoticed in the literature - quite on the contrary, most introductory text-books have not only recognised it but have, as I am inclined to believe, exaggerated its importance to the point of letting it eclipse the unique richness as well as the asyet-underexplored reach of Austin's original insights, the fact remains that a number of commentators have systematically attributed to the English philosopher ideas that they ought to have instead, in all fairness, creclited to his North-American disciple. ${ }^{1}$

Now, there is a fairly easy explanation for the fact mentioned above. There is a certain wide-spread belief that Searle's principal merit lies in having undertaken to, as it were, "streamline" his teacher's (supposedly) random and tentative thoughts on the topic of speech acts and related matters, giving them the form of a 'theory' in the rigorous sense of the term. Although such a claim is unexceptionable as far as it goes, it is guilty of injustice on two counts: one, to Austin and the other, to Searle.

The injustice to Austin is that it has prevented people from asking what the Oxford philosopher himself had to say on the different issues involved, and hence from looking at his writings at all, except through Searle's eyes. It is Searle's writings that are widely 
read, consulted and cited; to Austin is at best reserved some occasional "lip service". Here is how the author of a recent introductory text-book on pragmatics reports on the early development of the theory of speech acts: "Its main developers were the British philosopher John L. Austin (whose posthumous How to Do Things with Words (Austin, 1962) had an enormous impact on linguistic philosophy, and thereby on linguistics, especially in its pragmatic variant), and the American John R. Searle, who had studied under Austin at Oxford in the fifties, and who became the main proponent and defender of the former's ideas in the United States, and subsequently world-wide." (Cf. Mey, 1993: 109-110). In other words, after Searle appeared on the scene, most researchers were led to believe that what they read in his books (especially his first book - the one that won him world-wide recognition, viz., Speech Acts: An Essay in the Philosopby of Language (Searle, 1969), was nothing but Austin (in spirit) at his best and, in addition, Austin systematised (Levinson, 1982: 238). The reasoning behind such an attitude is the following: if it is indeed the case that what Searle did was simply systematise Austin's thoughts, it makes no sense whatsoever to bother about what Austin may have written on the same subject, for the simple reason that one is, after all, most likely to come across the very same ideas discussed in a philosophically far more lucid manner in the writings of his disciple.

The injustice to Searle consists in that the whole idea reduces the Berkeley philosopher to a mere 'second fiddler' whose only merit was that he happened to be at the right place at the right time. To put matters in a nut-shell: the vast literature on the theory of speech acts is replete with remarks that evidence an early misunderstanding of the role of John Searle in its development. In refusing to grant any originality worth the name to Searle's contribution to the field, many commentators have helped perpetuate the myth that there is a smooth continuity between the master and the disciple; that the one took over precisely where the other had left off. Nothing could be further from the truth. 


\section{OBJECTIVES}

In what follows, I will not pursue the above question any further. I will simply treat it as a matter of fact that the speech act theory as we know it today carries the label 'Made in U.S.A', although some of the basic ingredients that went into its making may indeed have been imported from England. My main concern in what follows will be with identifying some of the important traits of the ideology that underlies the speech act theory in its 'official' version. My main concern, in other words, will be with the fortunes of the theory in the hands of John Searle rather than the sort of treatment it was subjected to by its original creator, J.L. Austin.

Now, scientific theories are historical products and as such reflect the socio-political circumstances that attend their moment of elaboration and acceptance by the academic community at large. And the theory of speech acts is no exception to the rule. So one fruitful way to study the ideological presuppositions that underwrite a theory is to consider in some detail the circumstances of its origin.

\section{THE BIRTH OF THE THEORY AND THE PREVAILING INTELLECTUAL MILIEU}

The theory of speech acts was born in an intellectual climate characterised by an acute distrust of ideology, especially in the United States. During the decade of the fifties - or in 1955 (the year of Austin's William James Lectures at Harvard) to be more precise when the ideas of Austin (1962) first made their impact felt on the American philosophical community, and that of the sixties - or, to be more precise, the year 1969, when the theory in its 'spruced up' version (Cf. Searle, 1969) was announced to the academic publicthere was a general belief, albeit not entirely uncontested, in the U. S. that ideology was a thing of the past. The end of ideology so confidently proclaimed and celebrated by Daniel Bell (1965) came as a source of comfort to a generation that had barely begun to 
recover from the trauma of World War II, the worst spectacle the world had ever witnessed until then of a whole nation acting under the spell of a crazy ideologue and playing untold havoc upon the rest of mankind. The very subtitle of Bell's best-seller is highly suggestive: The Exhaustion of Political Ideas in the Fifties. In Europe, however, the intellectuals were a lot more cautious. Many, like the second generation theorists of the Frankfurt school knew all too well that totalitarian ideologies such as Stalinism and Leninism were still around and held a treacherously seductive charm for many of their otherwise well-meaning colleagues who found it perfectly normal that millions of people should be made to go through extreme. hardship and deprivation of their political rights in the name of public good and a future 'promised land'. "Ideology," wrote Bell (1968: 96), "is the conversion of ideas into social levers .... It is commitment to the consequence of ideas .... What gives ideology its force is its passion ... For the ideologue, truth arises in action, and meaning is given by the 'transforming moment'. Bell's English contemporary Ernest Gellner (1959: 1) had, barely a year before the former published his best-seller, defined ideology as "a system of ideas with a powerful sex appeal."

So ideology was passion, sex appeal and impulsive action. One had better defend oneself against its insidious effects. What was needed to hold it at bay was reason, self-control and thought. Thus when Raymond Aron (1968: 144) defined ideology as "a pseudosystematic formulation of a total vision of the historical world," his fury was directed singularly at the 'pseudo-systematic vision' rather than the idea of the 'total vision' or, for that matter, the idea of the 'historical world'. Aron, however, did not fail to notice a certain irony about the whole idea of decreeing the death of ideology, especially at a time when the world was witnessing the gruesome spectacle of the Cold War. Like many others, he fully recognised that, with the World War II over, the Peace had 'broken out'. Writing in 1957, he noted: 
It may seem rather paradoxical to envisage the end of the ideological age at a time when Senator [Josephl McCarthy continues to play a leading role on the Washington stage, when Les Mandarins has just won the Prix Goncourt and the flesh-and-blood "mandarins" are making the pilgrimage to Moscow and Peking. One is not so naive as to expect peace to blossom forth in the immediate future: the idealists disillusioned, the bureaucrats continue to reign. (Aron, 1968: 144).

But then Aron was the odd one out in his analysis. There was a general consensus that the American intelligentsia was no longer divided on an ideological basis. Talcott Parsons, a leading sociologist of the period, was to claim that sociology had made a "breakthrough" in the U.S. thanks to what he went on to describe as the country's intellectual openness and receptivity. For Parsons, what distinguished the American intellectuals of his day was their "relative immunity to the pressure to put problems in an ideological context." (Parsons, 1962: 313).

\section{IDEOLOGY IN THE CONTEXT OF ANALYTIC PHILOSOPHY}

In 1971, barely two years after the publication of his book on speech acts, Searle wrote a political treatise entitled The Campus War (Searle, 1971). ${ }^{2}$ Curiously enough, this work hardly ever gets even a passing mention in the literature on spejech acts and related matters. This may well have to do with the general tendency among analytic philosophers to go about their business under the impression that philosophy has no consequences on material life, and hence a philosopher's views on philosophical matters can have no impact on her beliefs on political and ethical issues, nor are they, for that matter, influenced in any way by the latter. In this sense at least, the analytic philosophers are at one with their adversaries in the pragmatist camp who have made a point of emphasising that philosophers would do well to keep their political views and 
religious beliefs strictly to themselves, not letting them interfere with their public work as philosophers.

It is probably needless to remind the reader at this juncture that the philosophers on the Continent, especially in France, are completely unlike their Anglo-Saxon colleagues in this respect, as the lives and works of Sartre, Foucault and more recently Derrida among countless others - amply demonstrate. In France, philosophy has always been self-consciously political and French philosophers have, as a matter of a general rule, not only not resisted the idea of making their philosophical reflections ideologically sensitive, but also, when challenged to act, frequently deemed it incumbent upon them to put their influence as philosophers at the service of political causes.

But the truth of the matter is that analytic philosophers, no matter how emphatically they may deny having any trucks with ideology, are no less ideologically committed. Furthermore, contrary to their own explicit claims, their philosophical views and ideological predilections can fairly easily be shown to be of a piece with one another. If nothing else, the very claim that theirs is a philosophy devoid of any ideological agenda can be shown to be itself a deft ideological gimmick par excellence. For, isn't it true that ideology at its best is ideology that successfully manages to pass for something else, preferably something supposedly the very antithesis of ideology - say, theory or science?

\section{FOCUS ON THE CAMPUS WAR}

A closer look at some of the central arguments contained in The Campus War will bear out our suspicions. In the next few paragraphs, I shall examine some of the main arguments of Searle in that book with a view to backing up my claim that the ideology that sustains his avowedly political treatise is also the one that underlies his work as a philosopher of language. 
Subtitled $A$ Sympatbetic Look at the University in Agony, The Campus War addresses the issue of the celebrated student unrest in the U.S., beginning at Berkeley in 1964, and soon spreading like wild fire throughout the length and breadth of the country. Although the author recognises that what happened on the university campuses in America was part of a world-wide trend, he makes no attempt to link it directly to the more famous student revolts in France or England.

Searle starts off with the observation that the course of history had shown within a matter of so few years that Daniel Bell and the other prophets of the doom of ideology were utterly wrong. Instead, observes Searle, the series of student revolts across the country "not a series of isolated incidents but ... a comprehensible and more or less discrete social phenomenon" (Searle, 1971: 5) - had proved beyond the shadow of a doubt that ideology was very much alive and kicking.

For Searle, the key to a proper understanding of the student unrest in the U. S. was that it was a "religious movement.":

.... by religious I do not mean that it has any necessary connections with any church or with a belief in the supernatural. Rather, I mean that it involves a search for the sacred. People in general, but especially young people have a need to believe in something and to act on behalf of something that they regard as larger than themselves. They need goals that they can regard as somehow transcending their own immediate needs and desire; these goals make more tolerable the mediocrity and insignificance of their daily lives. (Searle, 1971: 5).

Before proceeding any further, it may be worth the while to detain ourselves a little over Searle's initial diagnosis of student unrest and look at some striking similarities between it and what Richard Rorty was to say a decade and a half later about politics in general. ${ }^{3}$ Speaking at the Inter-American Congress of Philosophy at Guadalajara, Mexico, Rorty (Cf. MacCarthy, 1990: 360) recommended that 
... philosophy should be kept as separate from politics as religion ... We should think of politics as one of the experimental rather than of the theoretical disciplines.

It doesn't take any great ingenuity to identify in Searle's diagnosis all the essential ingredients of the typical pragmatist distrust of politics at the macro-level. For both Searle and Rorty (although, in all likelihood, neither of them would welcome the idea of being branded along with the other), politics is like religion in that in both cases what one is ultimately looking for is something really and truly sacred. Furthermore, both involve the exteriorization of a private, deeply inlaid need viz. the need for a father figure, be it the Godhead, Ataturk, Feuhrer, Duce, or quite plainly, the Father of the Nation. ${ }^{4}$

The one major difference between Rorty and Searle on the shared issue of keeping politics away from philosophy (in the final analysis, this may even help explain why the former ended up in the pragmatist camp while the latter continues to cling steadfastly to the good old analytic ideals) is that Rorty thinks that no philosophy can in principle come to the rescue of politics. By contrast, Searle seems to think that the problem with the student revolts is that they are impelled by passion bordering on the religious, rather than sober reasoning. Referring to the "extraordinary sense of community" (Searle, 1971: 5) and "the remarkable idealism" of "this generation of students" (Searle, 1971: 6), Searle goes on to observe: "Someone must play the role of the enemy. Indeed, lacking a coherent ideology, the in-group of US is defined by our shared hostility to the outgroup of THEM" (ibid). Surely, all this business of locating a common, formidable enemy in order to foster the in-group feeling is so very typical of the world's religions, from the most 'primitive' to the most 'sophisticated' - what else was Satan conjured up for, one might ask, if not to provide God with a raison d'être?

For Searle, what lies at the bottom of the student unrest is that the student body is under a religious spell: the solution therefore is to awaken them from their 'dogmatic slumber', as it were. "In this 
respect," continues Searle, immediately after the last passage cited in block quotation,

the style of this particular generation of student reformers sharply contrasts with that of the previous reformers. I can recall, for example, that when I was an activist student leader, we were constantly seeking the co-operation of other groups, even though they did not share our general outlook, and were even seeking the co-operation of administrators (Searle, 1971: 6-7).

To put matters simply, theirs is a god of strife. Ours, by contrast, was a god of harmony and co-operation - alas, what a pity that all that belongs to a bygone past!

What they fail to perceive is that, in general, efforts at compromise are doomed to failure simply because any compromise with the evil is regarded by the militants as morally unacceptable, a sell-out to the enemy (Searle, 1971: 7).

A sizeable portion of the rest of Searle's political treatise is taken up by an examination of how the three segments that make up the university - viz., the students, the administration, and the faculty react to the new set of circumstances. I shall skip over the details here. The general thrust of Searle's remarks may however be summarised as follows: the student body as a whole allows itself to be carried away by empty slogans and Utopian ideals; the administration watches dumbfoundedly, unable to decide what to do; while the members of the faculty either refuse to take a stand for fear of adverse reaction from the students or openly come out in their favour to gain easy popularity. Says Searle:

... it takes a good deal of courage today to oppose student radicals than it does to oppose university administrations and trustees. Blackmail is both particular and general; many professors support radical positions not out of personal fears, but in the hope of bringing peace to the campus. (Searle, 1971: 127-128). 
Chapter 6 of The Campus War contains arguments that are crucial to Searle's overall thesis. In this chapter, the author addresses the issue of academic freedom. Searle's basic strategy here is to argue that there are two concepts of academic freedom that are in theory distinct but in practice not always distinguished: the 'Special Theory' and the 'General Theory'. The special theory of academic freedom, says Searle, was imported from Gerrnany along with the very model of university for which, as many historians have registered, the early educationists in the United States turned to Germany rather than Great Britain. It basically consisted in the kind of thing encompassed by the German words Lebrfreibeit and Lernfreibeit i.e., the professors' right "to teach, conduct research, and publish their research without interference", and the students' right "to study and learn", respectively (Searle, 1971: 184). The general theory of academic freedom is tied to the society at large. Under it, the members of the academic community are said to have the same rights (and duties) as any other citizen qua citizen. If the special theory presupposes a theory of the university, the general theory makes sense only against the background of "a theory of society and of man's relation to society." (Searle, 1971: 191).

Having made the distinction between the special theory and the general theory, or between a narrow sense and a broad sense of academic freedom, Searle goes on to show how the two tend to get conflated all too frequently, although he hastens to add: "At one level the difference between those who accept only the Special Theory and, those, like myself, who accept the General and the Special Theories, is purely verbal. It all depends on what one means by 'academic freedom'" (Searle, 1971: 196).

But the fact that it is difficult to sustain the distinction at a conceptual level does not mean that it has no use at the level of practice. As a matter of fact, argues Searle, a university committed only to the special theory will have no objections to keeping a tab on the extramural activities of both the faculty members and the students. This is because such prized items as the freedom of speech 
and the right to support whatever political causes one chooses to are not part of the special theory; they belong to the general theory. Searle draws our attention to the fact the original conception of Lebrfreibeit did not include the right of the professor to engage in active politics - for the simple reason that it was developed in Imperial Germany, where the authority flowed exclusively from the emperor and always downwards. But when the concept was imported to the democratic United States where the ultimate authority was - at least on paper - "of the people, by the people, and for the people," such a restrictive idea of academic freedom had to be substituted by a more comprehensive one.

The difference between the Imperial Germany and the People's United States as far as the concept of university is concerned is, in Searle's view, quite simply the following: in Germany, the concept of academic freedom was developed as an exception to the rule; whereas in the U.S. it was, right from the very beginning, seen as a natural corollary to the general concept of freedom of the individual, enshrined in a democratic constitution.

Nevertheless, argues Searle, the Special Theory does not cease to have its usefulness at a pratical level. To quote him, "The General Theory incorporates the Special Theory because it includes the theory of the university, but adds to it the following: students and faculty members maintain as students and faculty members the same rights they have as citizens of a free society" (the emphasis is mine) (Searle, 1971: 192). In other words, care should be taken not to confuse between the rights of the students and the professors qua students and professors on the one hand, and the rights of the very same students and professors qua ordinary citizens. Searle therefore draws the conclusion that, in a democratic set-up, the freedom of speech that the students and teachers are entitled to qua students and teachers is confined to strictly academic matters. Any attempt to use the classroom for expressing political views would constitute overstepping the limits of the freedom guaranteed by the Special Theory. In Searle's own words, 
... the professor does not have unlimited free speech in the classroom. He is only entitled to lecture on the subject of the course or lecture series, and he is not entitled to use the classroom for, say, political propaganda. If he reconstitutes his lecture series as a political indoctrination session, he both violates the academic freedom of the student and abuses his academic freedom as a professor. The General theory is an extension of the concept of freedom, because under it the academic role preserves the rights accorded the citizenship role, except insofar as those rights are regulated to realize the purposes of the university. (The emphasis is Searle's) (Searle, 1971: 193).

Before proceeding any further, it is important to pause a little and ask if Searle's argument for the thesis that the professor has no right to express his political views in the classroom is all that cogent and self-evident as it seems at first blush. Recall that the whole argument rests on a certain distinction between two senses of academic freedom which Searle refers to as the 'Special Theory' and the 'General Theory'. Now, Searle himself was the first to admit that the distinction is far from being clear-cut at the conceptual level. Indeed, his only excuse for continuing to invoke the distinction was that he felt that the terms were still useful at a purely practical level. But then this note of caution is precisely what he forgets when he so confidently distinguishes the rights of the academics qua academics from the rights of the same academics qua ordinary citizens. For, how can he justify the putative distinction between the two sets of rights, other than by invoking a clear (mind you, not just practical, but conceptual) distinction between the Special Theory and the General Theory? It will certainly not do to say that we all know what rights a professor is entitled to as an ordinary citizen like anybody else and what additional rights she may lay a claim to as a member of the academic community she belongs to - a select group of people entrusted (by the community at large) with the task of furthering the cause of knowledge and higher education. Quite on the contrary, to the extent that such a distinction between the two sets of rights makes any sense at all, it already presupposes the prior 
acceptance of there being a clear-cut distinction between the Special Theory (the one that specifies the academic's rights as an academic) and the General Theory (the one that spells out an academic's rights as an ordinary citizen). In other words, Searle is simply begging the question when he claims to know in advance when a lecture ceases to be an academic matter and begins to take on political connotations - a conclusion that should come as no surprise, especially if one recalls that the very word 'academy' carries with it a whole history of political machinations and questionable governmental patronage in ancient Greece (Plato could comfortably label the sophists whom he despised as the 'peddlers of cheap knowledge' for collecting fees from their pupils, given that his own financial security was fully guaranteed by a generous subsidy to his State-sponsored Academy).

\section{THE RELEVANCE OF THE CAMPUS WAR TO SPEECH ACT THEORY}

What has all this got to do with the theory of speech acts? The answer is: quite a lot. As I wish to argue from now on, Searle's explicitly political treatise as contained in The Campus War foreshadows with admirable precision a number of theses he has zealously defended in the quarter of a century or so since the book saw the light of the day. The majority of these theses are among those that one would normally be inclined to classify as having to do with topics in the philosophy of language or the philosophy of mind (For Searle, the former is but a subdiscipline under the latter - Cf. Searle, 1992 for a categorical statement of this view). Yet Searle himself seems, as we have already noted, to hold the view that a philosopher's political views are entirely independent of her philosophical theses. I shall postpone further discussion of this matter until I have explored in some detail how Searle's political views dovetail neatly into his overall position as a philosopher of language.

Mary Louise Pratt (1981: 5) has suggested that the ideal speaker envisaged by the speech act theory is "an Oxford cricket player, or 
maybe a Boy Scout, an honorable guy who always says the right thing and really means it". Pratt goes on to add that the speech act theory thus distinguishes itself from the Bloomfieldean structural linguistics that imagined its ideal speaker as some sort of a linguistic Noble Savage, the Labovian sociolinguistics for which the ideal speaker is Eliza Doolittle, Bernstein's approach in which Lady Chatterly's lover emerged as the ideal speaker, and finally Chomskyan linguistics that puts forth an MIT graduate student as its ideal speaker. The facetious intent of these remarks aside, Pratt's remarks do capture an important truism about the prototypical subject of language around whom the theory of speech acts seems to have been so painstakingly constructed. For the speech act theory, the subject of language is a rational agent fully and always in control of her thoughts and decisions, cultured in middle class mannerisms (especially, as they are understood in the U.S.) politeness ("Would you be so kind as to ...."), table manners ("Could you please pass the salt?"), and all the rest of it.

The whole idea of indirect speech acts (Cf. Searle, 1975), for instance, crucially rests on the concept ol such a subject of language. For Searle, communication is an activity carried out by rational agents in accordance with a set of constitutive rules whose unwritten premise is the Principle of Co-operation formulated by Grice (1975). He says,

In indirect speech acts the speaker communicates to the hearer more than he actually says by relying on their mutually shared background information, both linguistic and non-linguistic, together with the general powers of rationality and inference on the part of the hearer (Searle, 1971: 60-61).

More interestingly however, Searle also claims en passant (Searle, 1975: 61) that the concept of indirect speech acts has important implications for the thesis in ethics which says that words like 'good', and 'right' etc. have an action-guiding meaning. Thus, just as one cannot conclude from the sentence 'Can you pass the salt?' 
that 'can' has an imperative meaning, so too, says Searle, it is foolhardy to conclude that 'good' has an action-guiding sense from the fact that to say about something that it is good is one way of recommending it.

\section{SEARLE AND THE ISSUE OF 'ETHICAL NATURALISM'}

The issue of ethics and rationality has been an important element in Searle's philosophical thought right from the very beginning. In a review article published in 1990 in The New York Review, he declares his conviction that the slow corrosion of moral requirements is to be blamed for the growing decline of academic standards. The following words of the philosopher are packed with a strong sense of nostalgia:

Why do we lack the confidence to require that each undergraduate acquire the rudiments of a good general education? After all, we were not always so lacking in self-confidence. When my grandfather graduated from Oberlin after the Civil war, he set out on his horse for what was then Indian ierritory, carrying Milton's Paradise Lost and the Bible in his saddle-bags. After the Second World War, when I began my education, it was no longer a matter of educating "Christian gentlemen," but we were quite confident of our theory of a liberal education. (Searle, 1990: 42).

Alongside of Philippa Foot (1967), Searle has had an important role to play in the revival of what is referred to as 'ethical naturalism' in the latter half of this century. Ethical naturalism is the thesis that says that moral judgements can perfectly well be logically derived from factual statements.

Historically, philosophers in the Anglo-Saxon world have as a matter of a general rule been averse to the idea of bridging the gap between fact and value. The classic statement of this view is to be found in Hume's Treatise, where one reads: 
In every system of morality, which I have hitherto met with, I have always remark'd, that the author proceeds for some time in the ordinary way of reasoning ... when of a sudden I am surpris'd to find, that instead of the usual copulations of propositions, $i s$, and is not, I meet with no proposition that is not connected with an ought or an ought not (Hume, 1888)

In his Principia Etbica, G.E. Moore (1903) declared it a fallacy to conflate the two kinds of statements and called it 'the naturalistic fallacy'. The idea that factual statements must be clearly distinguished from value judgements was also subscribed to by Bertrand Russell in the form of what is often called 'ethical subjectivism'. According to Russell (1935:237), "... if two men differ about values, there is not a disagreement as to any kind of truth, but a difference of taste." Ethical subjectivism subsequently gave way to the theory known as 'emotivism' whose principal advocates were Charles Stevenson (1963) and A. J. Ayer (1936), acclaimed by many as the principal spokesman for Logical Positivism in England. So much for a quick look at the philosophical dogma Searle was reacting to.

In Chapter VI of his Speech Acts, there is a whole section devoted to what Searle baptises 'the naturalistic fallacy fallacy' i.e., the fallacy of considering naturalism a fallacy. Searle contests the thesis defended by J.O. Urmson (1953: 120) that a term like 'valid' is an evaluative expression, so that "to call an argument valid is not merely to classify it logically, as when we say it is a syllogism or modus ponens; it is at least in part to evaluate or appraise it; it is to signify approval of it." For Urmson this means that what guarantees the validity of deductive logic is something necessarily external to it, since the claim that a deductive system is valid does not itself logically follow from its premises.

What Searle finds most objectionable in Urmson's thesis is the consequence that no system of logic, and hence, a fortiori, no codified set of propositions whatsoever, can be claimed to be selfsustaining and that all systems are therefore always open to question, no matter how impeccable their internal logic is. Searle on the other 
hand reveals himself committed to the position that the legitimacy of no code can be called into question without at the same time necessarily questioning its 'internal' logic. And as he would argue, what gives a system of deductive logic its internal rigour is the very principle of rationality. So for Searle even to doubt the validity of a deductive system is to be totally irrational. From Searle's point of view, then, Urmson's thesis must be wrong if only because it lays open the outrageous possibility that the logic of deduction may not be valid.

Before looking at Searle's specific arguments against Urmson, it is important to see in what way the whole issue is tied to a key idea defended by the Berkeley philosopher in his The Campus War. Recall that for Searle academic freedom has certain absolute limits (whose absoluteness is guaranteed by logic); an academic is not, for instance, entitled to question it from within the confines of the very system which instituted it in the first place (by using that freedom for, say, promoting her own political opinions). In other words, the validity of the system of principles we call academic freedom is guaranteed by the simple fact that one is enjoying it - for the simple fact of enjoying it means one is already an 'insider' to the system. Accepting the principle of academic freedom entails endorsing its absolute bounds; so an academic cannot both avail herself of the system academic freedom vouchsafed her and question the larger system that instituted it, because that can only be done by trespassing the very limits imposed by logic - or, what amounts to the same, by getting caught in a web of absurdity. The very illogicality of such a move will, in Searle's view, be sufficient ground for proscribing it - given his own case for ethical naturalism which authorises the passage from the descriptive 'is' to the ethical 'ought'. By the way, note that Searle's own strategy in arguing for there being strict limitations on academic freedom consists in deflecting the whole question from the domain of ethics to the domain of semantics and logic.

Searle's argument against Urmson, and indeed all those philosophers who have endorsed the thesis of naturalistic fallacy, 
is essentially a semantic one. He claims that although the expression 'valid' is indeed evaluative as Urmson rightly urges, the expression 'valid deductive argument' is perfectly well capable of being explicated in purely descriptive terms, contrary to what Urmson's thesis would predict. Searle's strategy consists in providing a definition such as the following for the expression in question. Here is his definition (Searle, 1969: 133):

$X$ is a valid deductive argument $=X$ is a deductive argument $d f$

and the premises of $X$ entail the conclusion of $X$

Since the right-hand side of the equational statement does not contain any evaluative expression, the thesis of naturalistic fallacy would predict that either (a) the equation as a whole is not true or (b) the left-hand side does not contain any either. But, says Searle, both (a) and (b) are false, and simultaneously so: the equation is correct and its left-hand side does contain an evaluative expression viz., 'valid'. Searle concludes therefore that the thesis of naturalistic fallacy must be false. (Searle considers and rejects the possibility of 'entail' being an evaluative expression on the grounds that there are a number of equivalent expressions such as "The conclusion follows logically from the premises' which can do the job just as well).

Searle's argument above does seem unexceptionable at first glimpse. There is, however, one important hitch. Searle has not really shown us that the right-hand side of the equation contains no evaluative element whatsoever. What about the expression ' $d f$ ' that Searle stealthily introduces at the beginning? For, a moment's reflection would reveal that, short of the force of the definition being invoked, there is no reason to accept the very equation, and hence, the whole question of validity itself depends on the definition being accepted unquestioningly. In other words, the truth of the equation, and hence the whole question of validity depends on the definition. 
There is, however, a nasty question that insists on cropping up at this stage: whose definition are we talking about? Why should it be binding on all and sundry? Recall that Urmson's whole point was that the validity of a deductive argument simply cannot be read off from its internal structure. All that Searle has shown is that it is definitionally guaranteed. But then that definition itself is by no means part of that internal structure. What is guaranteed by definition - here, as it is any where else - is guaranteed by fiat. As a matter of fact, if Searle had bothered to consult the list of verbs Austin gives under the category of performatives he calls 'expositives', he would have found the verb 'define' right there. And a quick look at Austin's remarks on 'expositives' would have convinced him that the matter is far from being that simple. Here are Austin's words:

Expositives are used in acts of exposition involving the expounding of views, the conducting of arguments, and the clarifying of usages and of references. We have said repeatedly that we dispute as to whether these are not verdictive, excercitive, behabitive, or commissive acts as well; we may also dispute they are not straight descriptions of ourfeelings, practice, \&c., especially sometimes over matters of suiting the action to the words, as when I say 'I turn next to', 'I quote', 'I cite', 'I recapitulate', 'I repeat that', 'I mention that'. (Emphasis added) (Austin, 1962:161)

Austin is here arguing that expositives behave in ways strikingly similar to imperatives in virtue of "suiting the action to the words"(or, as Searle himself was to characterise it later on (Cf. Searle, 1979), their 'words-to-world-fit').

In Chapter VIII of Speech Acts, Searle addresses another version of the thesis of naturalistic fallacy that turns on the metaphysical distinction between fact and value: the alleged. impossibility of deriving 'ought' from 'is', discussed by Hume in the passage cited earlier on. Searle's strategy here is to counter such arguments with facts about human institutions. This is in marked contrast with the strategy adopted by Philippa Foot (who has, by the way, abandoned her position since then - Cf. Norman, 1983: 234)). 
Foot's main argument consisted in trying to show that there are certain facts about human needs, wants etc. that are - as she believed at that time - absolute and universal.

Searle argues that within the institution of promising it is a fact that a person who has promised to do something has undertaken to do it. For Searle, the obligation to carry out the promise is constitutive of the very act of promising, and not something external to it. For Searle, in other words, it can be proved by dint of a series of analytic steps that the statement 'Jones uttered the words "I hereby promise to pay you, Smith, five dollars"' entails 'Jones ought to pay Smith five dollars'.

It is interesting to see how Searle's view of academic freedom and, more specifically, his view of the 'abuse' of academic freedom by those dons who use the classroom for giving vent to their political opinions, is an offshoot from his commitment to (his own brand of) ethical naturalism. Thus when he discusses what he calls the 'Special Theory' of academic freedom, the one that encompasses Lebrfreibeit and Lernfreibeit), Searle makes a point of observing the following:

It is important to emphasize at the very beginning that in the special theory the right to teach, conduct research etc., without interference are not general human rights like the right to free speech. They are special rights that derive from particular institutional structures, which are created by quite specific sets of constitutive nules. (Searle, 1971: 184-5)

It is noteworthy that a footnote indicated at the end of the passage quoted above directs the reader to Chapter II of the author's Speech Acts "for an explanation of the notion of constitutive rules". The so-called constitutive rules are contrasted with what Searle calls 'regulative' rules. "I am fairly conficlent about the distinction," says he, "but do not find it easy to clarify" (Searle, 1969: 33). Whereas "regulative rules regulate antecedently or independently existing behaviour", "constitutive rules do not merely regulate, they create or define new forms of behavior" (emphasis added). The italicised 
words clearly show that the regulative role is common to both kinds of rule, which means that one should be careful not to conclude, as Searle seems to implicitly, that constitutive rules are descriptive through and through (i.e., not prescriptive or normative as the rules of ethics typically turn out to be).

Anyhow, having made the distinction along the proposed lines, Searle does go on to note that "regulative rules characteristically take the form of or can be paraphrased as imperatives" (Searle, 1969: 34) but hastens to add that constitutive rules also can be expressed as imperatives. The important thing is the following caveat he enters:

If our paradigms of rules are imperative regulative rules, ... nonimperative constitutive rules are likely to strike us as extremely curious and hardly even as rules at all. Notice that they are almost tautological in character, for what the rule seems to offer is part of a definition ... (Searle, 1969: 34)

At this stage, we are in a much better position to understand Searle's position when he argues that

If [a professor] reconstitutes his lecture series as a political indoctrination session, he both violates the academic freedom of the student and abuses his academic freedom as a professor. (Searle, 1971: 193).

Now, surely no one would want to dispute Searle's claim that indoctrination is totally unbecoming of a university worth its name and hence unquestionably reprehensible in a university professor. But the point is: how do we know where teaching stops and indoctrination takes over? Any attempt to draw a neat line of demarcation between the two would require that we already have a clear distinction between what is strictly academic and what is in addition politico-ideological - an impossible requirement, given that, as noted earlier, the very word 'academy' has an etymology strongly reminiscent of an ideological tug of war between contending factions and unabashed state favouritism of one of them to the detriment of 
the other. Searle does try to address the question but it is easy to notice that he is at a loss. On the one hand, he admits (and here we can only agree with him) being sceptical about the claim made by certain university administrators to the effect that, as an institution, a university must be politically neutral. On the other hand, and somewhat paradoxically, he is equally not convinced by the arguments of those (Searle calls them 'radicals' ) who insist that, whether one likes it or not, the university can never be neutral. Thus he exclaims with evident reprobation: "Even refusing to take a stand on the war in Vietnam, the radicals argue, is itself a stand, since it gives tacit acquiescence to the present policy". 5

Searle's conviction as to why a university should keep away from politics is based on the argument that

the university has no right within the terms of its theory of legitimacy to become a political agency, and it would destroy itself as a university if it chose to do so. ... as a specialized institution it is not entitled to alter the terms of its contract with society and still retain its rights, any more than a hospital is entitled to turn itself into a theater or the Foreign Office of a country into a yachting club (Searle, 1971: 200-201).

Says Searle: "The failure to perceive the existence and nature of constitutive rules is of some importance in philosophy" (Searle,1969: 35) . "And in the world of practical affairs too," he could have added: But be didn't and it is not difficult to see why. As suggested at the beginning of this paper, analytic philosophers are not generally very enthusiastic about letting their philosophical views get reviewed alongside of their political views, or for that matter, even remotely admitting that the two sorts of views may have some ultimate connection. But it is very clear that, in Searle's case, his political views, or more mildly, his views on political matters, are of a piece with his views as a philosopher. Thus Searle's final message in The Campus War is that the failure on the part of the left-wing radicals to recognise that the university should not be allowed to get involved in politics is "a failure to perceive the existence and nature 
of a constitutive rule" viz., that "the university is an institution designed for the advancement and dissemination of knowledge" (Searle, 1971:185). Indeed, this is a string Searle has been fond of harping on ever since. Thus, in a recent article in Daedalus, Searle (1993) insists that there are two 'sub-cultures' in faculties, across departments, one "that of the traditional university, dedicated to the discovery, extension, and dissemination of knowledge as traditionally conceived" and another which he dismissively designates 'postmodernism'. (It is interesting to note here, albeit parenthetically, that in branding all those who do not fit into his cherished ideal of the traditional university as 'postmodernists', Searle implicitly considers postmodernism a radically left-wing movement - in direct contrast with someone like Fredrick Jameson (1991), for whom postmodernism bespeaks a right-wing ideology or in his own words, "the cultural logic of late capitalism". This in itself, I believe, is sufficient to show how slippery and ill-understood the term 'postmodernism' is in the context of contemporary intellectual scenario). Just how arbitrary and flippant Searle's accusations are would become immediately clear if one were to slightly modify one of the examples he cites in the last passage quoted above: would the fact that the particular Foreign Office he presumably has in mind has long served as a cover-up for activities not envisaged in the U.N. Charter thereby merely 'violate' a 'constitutive rule', or shouldn't we rather be suggesting that the repeated 'violations' of supposedly 'constitutive' rules justify an urgent revision of the very way we have traditionally viewed the venerable institution in question?

\section{CONCLUDING REMARKS}

Before rounding off our discussion, we must consider the fortunes of the 'naturalistic fallacy' in the light of all our discussion. Doesn't our finding that Searle's philosophical views on the topic of speech acts mesh in neatly with his allegedly unconnected views on 
political issues constitute strong evidencie in favour of his own thesis of 'the naturalistic fallacy fallacy"? The answer is that it does not. Ethical naturalism states that 'ought' is derivable from 'is'. The question as to whether the reverse of this process also holds good is hardly ever contemplated by those who address the issue. Rather, the derivational history is typically viewed as inconsequential. For a hard-core analytic philosopher history is anathema and all appeal to history pure gibberish. Cold-blooded reasoning, they say, is ahistoric, and reason itself immune to the laws of history. So the real issue, they would argue, is not whether 'ought' is derivable from 'is' or the derivation works the way round, i.e., it is 'is' that is to be derived from 'ought'. The real issue, they would insist, is that 'is' and 'ought' do not belong to water-tight compartments. Thus the major thrust of Searle's arguments against the thesis of naturalistic fallacy is that, given the rules of general human conduct and morality - and more specifically, the fundamentals of his own version of the speech act theory, 'ought' can clearly be demonstrated to follow from 'is'.

Now, Searle's thesis is open to a fairly obvious objection. The 'is' from which he claims to be able to derive the 'ought' is not the familiar ontological 'is'. Within the terms of his own claims as to the ubiquitous nature of the speech act, it would follow that the 'is' in question is the product of an act of assertion by someone. To recall Searle's own example of the case of promise, the utterance of the would-be debtor "I promise to pay etc." has to be ratified and endorsed by a third-party before it can become " $\mathrm{X}$ promised $\mathrm{Y}$ to pay etc.". What we should not lose sight of in this passage from a first person (hence, presumably 'subjective') to the third person (hence, presumably 'objective') premise - or, equivalently, to the validity of the premise ' $\mathrm{X}$ is a (moral) debtor' (the one from which Searle triumphantly derives the 'ought' statement) - is that the thirdparty endorsement is not itself a constitutive act; it is a regulative one to the extent that the felicity of the illocutionary act of promise is simply not to be read off from the words themselves but from an 
appreciation of a host of extraneous factors including the attendant circumstances. In other words, what Searle derives his 'ought' from is not an ontological 'is' but an 'is' whose validity is a function of the regulative powers invested in the third-party that authorises the move; its validity, in other words, is assertorial, not ontological.

More interestingly, however, there is a sense in which Searle's arguments against the thesis of 'naturalistic fallacy' may be seen as in fact backfiring. The primary, if not the ultimate, aim of those like Searle who advocate ethical naturalism is to urge that certain moral choices are not choices at all, but follow logically, and hence unnegotiably, from certain factual statements. In the ultimate analysis, this is Searle's strongest argument against the political involvement of university professors: a university being what it is (Never mind who has the final say on this or any other question), a professor who recognises her role as eminently political is logically trespassing the bounds of the cognitive space allocated to her. But our brief discussion of the issue seems to indicate precisely in the opposite direction. For in Searle's own case, not only his political views, but also his self-proclaimedly non-political philosophical views (on such topics as speech acts) turn out, upon closer inspection, to be underwritten by the same ideological agenda.

\section{NOTES}

${ }^{1}$ This paper is part of an ongoing research project financed by CNPq (Grant no. 306151/88-0). I am grateful to Carlos Franchi and Rodolfo Ilari for going through earlier versions of this paper. Needless to say, I alone am responsible for the views expressed.

2 'The first chapter of this book, entitled 'The anatomy of student revolt', had already been published in the form of an earlier version in The New York Times Magazine, December 29, 1968, under the catchy title 'A foolproof scenario for student revolts'. 
${ }^{3}$ Of all contemporary philosophers who identify with pragmatism, Richard Rorty has been remarkably consistent on this issue. In his several books (Cf. Rorty, 1982, 1989), he has tirelessly argued for a neat separation of philosophy and politics. Unlike the Continental philosophers whom he otherwise admires a great deal, Rorty is of the opinion that the enterprise of philosophy has outlived its usefulness.

${ }^{4}$ Interestingly enough, Searle considers and immediately rejects (p.2) the possible explanation of the student revolt as "an Oedipal response of hatred for father symbols". In Searle's view, the students see the revolts, quite on the contrary, as a way of escaping from "the mediocrity and insignificance of their daily lives". In other words, according to Searle, it is the clesperate need for a father figure that makes the students behave the way they do - the kind of a father figure that presumably the society at large, including the university authorities, had failed to provide them with. In other words, for Searle, it is the absence of paternal authority that is the root cause of all the confusion on the campus. On closer inspection, all this is but the ancient wisdom as encapsulated in the English proverb: Spare the rod and spoil the child.

${ }^{5}$ Recall that the U.S. policy on Vietnam was the one key issue on which the Federal Government found itself at loggerheads with the university intelligentsia.

\section{REFERENCES}

ARON, R. (1968). The Opium of the Intellectual. New York: Doubleday \& Co. AUSTIN, J.L. (1962). How to Do Things with Words. Oxford: Clarendon Press. AYER, A.J. (1936). Language, Truth, and Logic. London: Victor Golancz.

BELL, D. (1965). Ideology and Utopia: The Exhaustion of Political Ideas in the Fifties. N.Y.: Harcourt, Brace \& World.

(1968). 'The end of ideology in the west'. In C.I. Waxman (Ed.) (1968). The End of Ideology Debate. N.Y.:Funk \& Wagnalls Pp. 87-105.

COLE, P. and J.L. MORGAN (Eds.). (1975). Syntax and Semantics Vol. 3. Speech Acts. N.Y.: Academic Press..

FOOT, P. 'Moral beliefs' (1967). In P. Foot (ed.). (1967). Theories of Etbics. London: Oxford University Press..

GELLNER, E. (1959). Words and Things: An Examination of, and an Attack on, Linguistic Philosopby. London: Routledge \& Kegan Paul.

GRICE, H.P. (1975). 'Logic and conversation'. In P. Cole and J.L. Morgan (eds.) (1975). Pp.41-58. 
HUME, D. (1888). A Treatise of Human Nature. L.A. Selby-Bigge, ed. Oxford. JAMESON, F. (1991). Postmodernism, Or, The Cultural Logic of Late Capitalism. Duke University Press.

LEVINSON, S.C. (1983), Pragmatics. Cambridge: Cambridge University Press. MACCARTHY, T. (1990). 'Private irony and public decency: Richard Rorty's "new Pragmatism". Critical Inquiry. vol. 16. No. 2. Pp. 355-370.

MEY, J.L. (1993). Pragmatics: An Introduction. Oxford: Blackwell. MOORE, G.E. (1903) Principia Ethica. Cambridge: Cambridge University Press. NORMAN, R. (1983). The Moral Philosophers. Oxford: Clarendon Press.

PARSONS, T. (1962). 'The point of view of the author'. In M. Black (Ed.) The Social Theories of Talcott Parsons. N.J.: Englewood Cliffs. Pp. 313-315.

PRATT, M. L. (1981). 'The ideology of speech act theory'. Centrum. New Series. Vol. 1. No. 1. Pp.5-18.

RORTY, R. (1982). Consequences of Pragmatism. Minneapolis: University of Minnesota Press.

(1989). Contingency, Irony, and Solidarity. Cambridge: Cambridge University Press.

RUSSELL, B. (1935). Religion and Science. London: Unwin.

SEARLE, J.R. (1969). Speech Acts: An Essay in the Pbilosophy of Language. Cambridge: Cambridge University Press. (1971). The Campus War. N.Y.: The World Publishing Co. (1975). 'Indirect speech acts'. In P. Cole \& J.L. Morgan (Eds.).(1975). Pp.59-82.

(1979). 'A taxonomy of illocutionary acts'. In J.R. Searle Expression and Meaning. Cambridge: Cambridge University Press. Pp.1-29. 6, 1990.

(1990). 'The storm over the university.' The New York Review. December, (1992). The Rediscovery of the Mind. Cambridge, Mass.: The MIT press. 55-83. (1993). 'Rationalism and realism: what is at stake?' Daedalus. 1993. Pp.

STEVENSON, C. L. (1963). 'The emotive meaning of ethical terms'. In C.L. Stevenson. Facts and Values. New Haven: Yale University Press.

URMSON, J.O. (1953) 'Some questions concernng validity' Revue Internationale de Philosophie. Reprinted In A.G.N. Flew (Ed.) Essays in Conceptual Analysis. 1956. London: Oxford University Press. 